\section{Borka D. Malčić}

Univerzitet u Novom Sadu,

Filozofski fakultet doi: 10.19090/zop.2018.27.85-104

UDC: $796.011 .1-057.875$

796.077.2-057.875

Pregledni rad

\title{
TEORIJSKE OSNOVE SAMORAZVOJA I SAMOEFIKASNOSTI ODRASLIH U KONTEKSTU NJIHOVIH INTERESOVANJA ZA FIZIČKE AKTIVNOSTI*
}

\begin{abstract}
Apstrakt. Interesovanja predstavljaju relativno trajnu usmerenost aktivnosti pojedinca prema određenom objektu. Iako značajna u svim uzrastima, u odraslom dobu interesovanja predstavljaju dispozicije ličnosti. Na složenost fenomena interesovanja, pored samog definisanja, ukazuje i postojanje velikog broja karakteristika interesovanja. U radu su sa teorijskog aspekta analizirani samorazvoj i samoefikasnost kao karakteristike interesovanja odraslih za fizičke aktivnosti koje su se pokazale značajnim činiocima i u empirijskim istraživanjima. Samorazvoj je posmatran iz tri ugla: kretanja ka autonomnosti, odnosno samoinicijative pojedinca; razvojnih zadataka i self koncepta individue. Analizirana je samoefikasnost koja određuje ponašanje pojedinca i aktivnost pri određenom interesovanju. Dat je prikaz veze percipirane samoefikasnosti i učešća odraslih u fizičkim aktivnostima. Sumiranjem rezultata zaključeno je da naredna istraživanja treba da budu usmerena na proveru u kojoj meri i u kojim vrstama fizičkih aktivnosti samorazvoj i samoefikasnost utiču na interesovanja za fizičke aktivnosti kod odraslih.
\end{abstract}

Ključne reči: interesovanja, samorazvoj, samoefikasnost, odrasli, fizička aktivnost.

\section{UVOD}

Iako se smatra da su interesovanja stara koliko i čovek, posmatrano iz naučnog ugla, razvojem društvenih nauka i porastom njihovog društvenog značaja, interesovanja počinju da budu predmet velikog broja naučnih disciplina, među kojima je i pedagogija. Interesovanja predstavljaju deo aktivne prirode čoveka, pa tako nema individue koja ne poseduje određenu interesnu strukturu. Iako je značaj interesovanja gotovo očigledan, brojni autori su se bavili formalnim određenjem, razvojnim fazama i

\footnotetext{
*Borka Malčić, borka.malcic@ @ff.uns.ac.rs
} 
karakteristikama ljudskih interesovanja kao vrednosti (Pantić, 1982; Savićević, 1992).

U svim periodima života interesovanja imaju značajnu ulogu, ali u odraslom dobu ona postaju jedan od pokazatelja zrelosti ličnosti. O "pravim" interesovanjima moguće je govoriti tek nakon dostignutog određenog stepena u socijalnom, kognitivnom i fizičkom razvoju i svršenog procesa diferencijacije emocija. Iako se smatra da je sredina činilac koji u najvećoj meri utiče na sve vrtse interesovanja (Savićević, 1992), sa promenom životnog toka čoveka, odnosno životne situacije u kojoj se individua nalazi, menjaju se i njegova interesovanja (Oljača, 2013). Iz ovoga se može zaključiti da su interesovanja odraslih relativno trajna usmerenost aktivnosti prema određenom objektu, što je promenljivo i zavisi od velikog broja kako ličnih tako i sredinskih faktora.

Postojeće teorijsko utemeljenje o interesovanjima predstavlja bitnu pretpostavku empirijskih istraživanja ove pedagoške i andragoške oblasti. Doskoro je predmet većine istraživanja o interesovanjima odraslih bio isključivo povezan sa profesionalnim interesovanjima i sa vrstama interesovanja u slobodnom vremenu. Poslednjih godina autori se bave kako teorijama nastanka interesovanja tako i određenim interesovanjem - sa ciljem da uoče razloge nastanka, zadržavanja ili promene određene interesne sfere.

Opredeljenje za interesovanja vezana za fizičke aktivnosti odraslih, leži u činjenici da veliki broj istraživanja pokazuje da je dve trećine svetske populacije fizički nedovoljno aktivno (Trost et al., 2002), a izveštaj Svetske zdravstvene organizacije (WHO, 2002), kaže da je nedovoljna fizička aktivnost predstavlja globalni problem i samostalni faktor rizika od smrtnosti. 
U radu će biti analizirani samorazvoj i samoefikasnost kao odvojeni faktori koji utiču na interesovanja za fizičke aktivnosti kod odrasle populacije.

\section{POJAM I KARAKTERISTIKE INTERESOVANJA}

Biti zainteresovan za nešto znači prema tom objektu interesovanja imati pozitivna osećanja. Interesovanja odraslih predstvaljaju pretežno trajne dispozicije ličnosti, koje su rezultat istorijskog razvoja; formiraju se $\mathrm{u}$ socijalnom kontekstu, pod uticajem sve većeg broja činilaca koji determinišu nastanak, razvojni put i zadržavanje svakog interesovanja. Ako se orijentišemo samo na definisanje pojma interesovanja iz pedagoškog odnosno andragoškog ugla, možemo reći da je konstrukt interesovanja prvi počeo da koristi Herbart. U Pedagoškom leksikonu (1996: 204) interesovanja su definisana kao "trajnija ili duža mentalna usmerenost subjekta prema nekom području ili određenim sadržajima; veća osetljivost ili prijemčivost za takve sadržaje; povoljniji emocionalni odnos prema nekom području, pojedinim sadržajima ili nekim licima”. S obzirom na krajnje parcijalne definicije koje se mogu naći prilikom analize teorijskih istraživanja, dolazi se do zaključka da se definicije interesovanja razlikuju u odnosu na ugao različitih teorija a da svaka od definicija sadrži emocionalnu, kognitivnu ili konativnu komponentu. Kada je reč o interesovanjima za fizičke aktivnosti, pogotovo u odraslom dobu, sve tri komponente neophodne su za postojanje interesovanja. Važnost kognitivnog aspekta vidi se već u samom znanju o značaju fizičke aktivnosti za sveukupno zdravlje. Dalje, emocionalna komponenta nalazi se u svakoj aktivnosti koja ispunjava slobodno vreme odraslih i na kraju konativni aspekt interesovanja za fizičku aktivnost kod odraslih predstavlja akcijsku spremnost za ponašanje u skladu sa sopstvenim 
interesovanjem. Zaključak je da uvažavanjem sva tri njegova aspekta, interesovanje predstavlja relativno trajnu usmerenost ličnosti prema nekom objektu, koja je pod uticajem različitih osobina same ličnosti, kao i pod uticajem sredine, socijalnog učenja i lične aktivnosti praćene prijatnim osećanjima i zadovoljstvom.

Kategoriju interesovanja u andragogiju uvodi Torndajk. Sumiranjem njegovih saznanja iz brojnih teorijskih i empirijskih istraživanja ove oblasti, može se uočiti da su neka interesovanja ukorenjena u prirodi same ličnosti intrinzička interesovanja - i da naglasak treba da je na njima; da interesovanja mogu da se modifikuju i nauče i da su opadanja u interesovanjima sa godinama neznatna (Savićević, 1992).

Na složenost fenomena interesovanja, pored samog definisanja pojma, ukazuje i postojanje brojnih faktora interesovanja. Činilac koji svakako u najvećoj meri diferencira interesovanja kod odraslih jeste sredina. Sredina može da se javi kao podsticaj i da pozitivno utiče na interesovanje, ali, takođe, može da bude i barijera u ostvarenju određenog interesovanja. U sredinske uticaje spadaju socijalne promene i socijalne vrednosti. Aktuelizacijom značaja fizičkih aktivnosti za zdravlje, fizičke aktivnosti procenjuju se kao određena vrednost, a od socijalne sredine direktno zavisi gde će one zauzeti mesto u životu pojedinca. Karakteristika interesovanja je i socijalno iskustvo individue determinisano položajem pojedinca, što može da vodi razmevanju izbora njegovih interesovanja u životu. Kao što je već napomenuto, životna uloga ili situacija, kao i životne okolnosti, takođe određuju vrstu i intenzitet interesovanja odraslih. Istraživnja su pokazala da su socijalno-ekonomske karakteristike pojedinca u vezi sa ostvarivanjem određenog interesovanja (Savićević, 1992). I za kraj, kao jednu od 
najvažnijih sredinskih karakteristika interesovanja, treba navesti porodičnu sredinu koja može da bude početna "škola" kod formiranja interesovanja ali i izuzetan ometač ili podsticaj u odraslom dobu.

Pored uticaja sredine, kao najdominantnije karakteristike interesovanja odraslih. izdvajaju se:

- biološka osnova, odnosno urođena dispozicija za određeno interesovanje (Olport 1969; prema: Pantić, 1982);

- motivi kao pokretačka snaga koja čoveka podstiče na aktivnost; broj i vrsta interesovanja pozitivno koreliraju sa sposobnostima, ostvarenim uspehom i inteligencijom individue (Savićević, 1992);

- interesovanja su vaspitljiva, mogu da se modifikuju i nauče;

- na razvoj interesovanja značajan uticaj imaju različiti spoljašnji faktori (Savićević, 1992);

- emocije su jedna od karakteristika interesovanja na svim uzrastima;

- postoji difrencijacija interesovanja s obzirom na starost i obrazovni nivo odraslih;

- socijalni činioci predstavljaju faktor formiranja, zadržavanja i promene $\mathrm{u}$ interesovanjima odraslih.

Pored ovih karakteristika, kao determinante interesovanja značajni su i samorazvoj i samoefikasnost individue (Hofer, 2010; McAuley \& Blissmer, 2000), koji će detaljnije biti analizirani u nastavku.

\section{SAMORAZVOJ U KONTEKSTU INTERESOVANJA ODRASLIH ZA FIZIČKE AKTIVNOSTI}

Razvoj odraslih podrazumeva periodične promene, sa pravilnim i specifičnim karakteristikama i stavovima koje odrasli doživljavaju tokom vremena (Oljača, 2005). Svaki čovek se bori i nastoji da otkrije svoj identitet, 
odnosno kakav zaista jeste i kakav želi da bude (Oljača, 1992). Ovakvo traganje za sobom i sopstvenim samoprihvatanjem i samoostvarenjem čini samorazvoj. Čovek u sebi nosi nagon da ide prema sve višem razvoju sposobnosti, da bude samostalan i da ostvari svoje maksimalne mogućnosti. Rodžers je među prvim autorima pisao o samorazvoju. Prema njegovom mišljenju, to su promene koje neko može da dostigne za sebe ukoliko želi i zna kako (Rogers, 1961). Samorazvoj praktično predstavlja dinamički proces nastajanja onog što osoba stvarno jeste. Rodžers navodi (Rogers, 1961) da postoji devetnaest principa na osnovu kojih se može objasniti i bolje razumeti i realizovati teorijska osnova za pospešivanje samorazvoja individue.

1) Svaka individua nalazi se u promenljivom svetu iskustva i doživljaja, gde je ona sama centar zbivanja.

2) Nakon doživljaja i iskustva, pojedinac reaguje na sredinu koja postaje njegova realnost.

3) Organizam reaguje kao organizovana celina u odnosu na to fenomenološko polje.

4) Osoba poseduje težnju da se ostvari i aktuelizuje, gde je osnovna pretpostavka individualna percepcija.

5) Svako ponašanje je usmereno ka određenom cilju.

6) Emocije su sastavni deo svrsishodnog ponašanja i njihov intenzitet zavisi od značajnosti ponašanja za razvoj organizma.

7) Najbolji pristup za razumevanje ponašanja je unutrašnji okvir same individue, koji se može otkriti samoempatijom.

8) Sazrevanjem se deo totalnog perceptivnog polja diferencira na self i na organizam. 
9) Kao rezultat interakcije sa sredinom i evaluacije interakcije sa drugima, formira se struktura selfa kao okvir percepcija koji karakteriše ja i mene prema drugima.

10) Vrednosti kao elementi iskustva i strukture selfa su, u stvari, vrednosti koje je osoba doživela ili preuzela od drugih.

11) Iskustvo se stiče a potom shvata i organizuje u self; ignoriše ili odbacuje iz selfa.

12) Načini ponašanja koje individua usvaja su oni koji se uklapaju u self.

13) Ako se ponašanje ostvaruje pod uticajem organiskih doživljaja i potreba a da nije pre toga simbolizovano, ono kao takvo "ne pripada" individui.

14) Psihološke tenzije nastaju kada individua svesno odbacuje značaj osećanja koje ne organizuje u geštalt strukture selfa.

15) Psihološka prilagođenost nasuprot tome nastaje kada su self koncept i svi senzorni doživljaji organizma povezani konzistentnim vezama.

16) Nekonzistentna iskustva sa selfom mogu da izazovu strah $i$ rigidniju organizaciju self strukture kako bi se ona zaštitila i sačuvala.

17) Odsustvom svakog straha sa druge strane pod određenim okolnostima i nekonzistentni doživljaji mogu da budu prihvaćeni u strukturu selfa i da utiču na njegovo revidiranje.

18) Ukoliko osoba prihvata sve senzorne i visceralne doživljaje u konzistentan i integrisan sistem, tada je, kao osobena ličnost, više prihvaćena u socijalnom okruženju. 
19) Sa prihvatanjem doživljaja, individua se menja i pretvara svoj postojeći self u organizmički proces vrednovanja.

U kontekstu interesovanja za fizičke aktivnosti odraslih, samorazvoj se može posmatrati iz tri ugla:

1) kretanja ka autonomnosti;

2) razvojnih zadataka;

3) self koncepta.

Prvi je koncept kretanja ličnosti ka višem nivou autonomnosti ondosno odabiru ciljeva koji žele da se dostignu kroz aktivnosti i ponašanja koja su u skladu sa ličnim vrednostima. Kada je reč o interesovanjima za fizičke aktivnosti, ovo bi značilo da će se ona ostvariti ukoliko individua ima razvijenu svest i poseduje potrebna znanja o značaju fizičkih aktivnosti za sveukupno zdravlje. Kako navodi Oljača (2005), ljudsko ponašanje može se menjati, odnosno do samorazvoja može da dođe samo u slučaju:

1) razvijanja individualnog osećanja ostvarenosti;

2) razvitka unutrašnjih snaga koje usmeravaju i podstiču aktivnost ličnosti;

3) razvoja individualnog self koncepta.

Primenom ovih postavki može se zaključiti da će odrasli razviti stabilna individualna interesovanja za fizičke aktivnosti ukoliko postoji samoinicijativa bez obzira na stimuluse spolja, ali da samorazvoja i razvoja interesovanja nema bez procesa učenja odnosno doživljenog pozitivnog iskustva. Ovo je od izuzetnog značaja za mogućnost primene prilikom učvršćivanja interesovanja za fizičke aktivnosti odraslih. Uz neophodnu samoinicijativu i pomoć kroz kognitivna saznanja a kroz doživljena iskustva 
(gde je poželjno postizanje uspeha), osoba će razviti interesovanje za fizičke aktivnosti u stabilnu dispoziciju svoje ličnosti.

Drugi koncept samorazvoja u kontekstu interesovanja odraslih za fizičke aktivnosti su razvojni zadaci. Koncept razvojnih zadataka predstvalja nastojanje da se proces starenja opiše kroz periode koji su svaki za sebe usmereni na zadatke i vrednosti i za koje se smatra da su poželjni, prihvatljivi i mogući. Razvojni zadatak javlja se u određenom periodu života i njegovo uspešno savladavanje vodi sreći, uspehu i blagostanju, kao i prelasku na naredne zadatke (Hofer, 2010). Pojam razvojnih zadataka ima dve implikacije na razvoj individualnih interesovanja za fizičke aktivnosti odraslih (Hofer, 2010), a one su sledeće.

1) U svakom životnom periodu, kroz svakodnevne izazove, osoba teži nekolikim ciljevima - neki od njih zavise od uzrasta i određenog zadatka.

2) U svakom narednom periodu osoba se susreće i bori sa životnim zadacima i u zavisnosti od toga intenzitet i vrsta interesovanja može da se promeni.

Gledano iz razvojne perspektive, osoba bi trebalo da smanji zahteve $\mathrm{u}$ ciljevima i zadacima kako bi se oni postepeno povećavali (Brandstadter, 1998). Može se zaključiti da je koncepcija razvojnih zadataka veoma korisna i značajna za razvoj individualnih interesovanja za fizičke aktivnosti individue, što se može ali ne mora razviti kroz višestruke ciljeve povezane sa idealnim selfom. Samo će ciljevi i zadaci koji nisu podstaknuti interesovanjima nestati nakon dostignuća (Hofer, 2010).

Treći koncept samorazvoja u kontekstu interesovanja je self koncept individue. Najvažniji ciljevi svake osobe su u vezi sa njenim self konceptom. 
Self koncept (self concept) jeste, najjednostavnije rečeno, skup stavova i mišljenja koje osoba poseduje o sebi. On se najčešće definiše kao vrsta trajne teorije koju osoba ima o sebi (Epstein, 1973). Self koncept u sebi sadrži kako prošlost tako i budućnost individue. S obzirom da osobe imaju tendenciju da definišu sebe kroz svoje hobije, jasno je da su interesovanja od ključne važnosti za self koncept pojedinca. Moguće je pronaći i vezu između interesovanja i četiri glavne perspektive selfa koje je predložio Strang (1957):

1) osnovni (stvarni) self je koncept za koji osoba smatra da je to ona; ovde bi karakteristična bila stvarna interesovanja osobe;

2) privremeni (prolazni) self je trenutno stanje i raspoloženje pojedinca; tu se ubrajaju interesovanja koja traju kratko i koja iz situacionih nisu prešla u individualna;

3) društveni self je onaj za koji osoba smatra da ga drugi vide i vrednuju; karakteristična interesovanja bi bila ona za koje osoba pretpostavlja da ih poseduje radi društveno poželjnih principa;

4) idealni self je onaj koji individua priželjkuje, ono što bi želela da bude, a uključivala bi ona interesovanja u kojima osoba želi da učestvuje.

Može se zaključiti da je stvarni samorazvoj povezan sa procesima samoodgovornosti i samoinicijative (Oljača, 2001). On proizilazi iz prirodne potrebe čoveka i mora posedovati karakteristike već doživljenog odnosno iskustvenog učenja. Svi oni koji imaju više i složenije životne ciljeve usmeravaju se ka samorazvoju.

S obzirom da su interesovanja za fizičke aktivnosti isključivo u vezi sa ličnim potrebama i željama pojedinca, očigledno je da ona ne mogu da budu razvijena ukoliko nema samorazvoja individue. Samo adekvatna 
saznanja, individualna odgovornost, samoinicijativa, kao i pozitivno doživljeno iskustvo bavljenja fizičkim aktivnostima, mogu da dovedu do stvarnog samorazvoja povezanog sa interesovanjima za fizičke aktivnosti.

\section{SAMOEFIKASNOST U KONTEKSTU INTERESOVANJA ODRASLIH ZA FIZIČKE AKTIVNOSTI}

Samorazvoj je u tesnoj vezi sa self konceptom osobe. Poznato je da slični ljudi biraju potpuno različita polja interesovanja, što je u skladu sa njihovim ličnim shvatanjima o osobinama za koje smatraju da poseduju, u odnosu na ono što misle da su u stanju da urade i, na kraju, naspram toga kako vide sebe u odnosu na druge. Ovakva shvatanja proizilaze iz čovekovog iskustva i karakteristika selfa. Ta subjektivna uverenja o sebi - kada se jednom uspostave - imaju veoma značajnu ulogu u samorazvoju svake osobe (Bandura, 1997; Markus \& Nurius, 1986). Dosadašnja istraživanja pokazala su da na većinu aktivnosti i izbora u ljudskom životu u značajnoj meri, pored self koncepta, utiče i uverenje o samoefikasnosti (Bong \& Skaalvik, 2003). Koncept samoefikasnosti razvio je Albert Bandura sedamdesetih godina XX veka. On određuje samoefikasnost (Bandura, 1977, 1997) kao uverenje pojedinca o sopstvenim sposobnostima organizacije i izvršenja određenih akcija koje su neophodne kako bi se ostvario postavljeni cilj. Samoefikasnost je, u stvari, subjektivni doživljaj ličnih kompetencija koje se tiču ostvarenja različitih zadataka.

Savremeni autori smatraju da samoefikasnost nije nasledna nego da se razvija kroz iskustvo (Maddux, 2002). Najčešće navođeni izvori na osnovu kojih osoba bazira ličnu efikasnost su sledeći.

1) Sopstveno iskustvo - uspeh povećava nivo samoefikasnosti, dok ga neuspeh smanjuje (Gist \& Mitchell, 1992; Saks, 1995; Silver et 
al., 1995). Ovo je veoma važno za interesovanja za fizičke aktivnosti jer se obezbeđivanjem uspeha $u$ ovim aktivnostima omogućuje nastavak učestvovanja u njima, dok neuspeh odnosno smanjen nivo samoefikasnosti može lako da dovede do prestanka bavljenja fizičkim aktivnostima odraslih.

2) Iskustva drugih - omogućavaju poređenje sa sopstvenim iskustvima kao i učenje po modelu (Bandura et al., 2003).

3) Verbalno/socijalno uveravanje - individua može biti podstaknuta i stimulisana na učešće u fizičkim aktivnostima, što povratno može da utiče na napredak u izvršavanju i samoprocenu efikasnosti (Redmond, 2010).

4) Psihofiziološko stanje - prijatna situacija povećava sigurnost, dok se neprijatna stanja povezuju sa osećanjem nekompetentnosti, u ovom slučaju za fizičke aktivnosti.

5) Imaginarna iskustva - iskustva u hipotetičkim situacijama mogu pozitivno ili negativno da utiču na percipiranu samoefikasnost (Maddux \& Gosselin, 2003).

Samoefikasnost u velikoj meri određuje naše ponašanje i aktivnost pri određenom interesovanju. Koncept samoefikasnosti primenjuje se u različitim oblastima: psihologiji, obrazovanju, sociologiji, medicini, menadžementu, sportu itd.

Dosadašnjim istraživanjima utvrđeno je da je percipirana samoefikasnost jedan od ključnih pokretača i razlog zadržavanja učešća $u$ fizičkim aktivnostima (Dzewaltowski, Noble, \& Shaw, 1990; Feltz \& Riessinger, 1990; McAuley, 1992, 1993; Shaw, Dzewaltowski, \& McElroy, 1992). Takođe, autori naglašavaju recipročnu vezu između fizičkih aktivnosti 
i samoefikasnosti i daju shematski prikaz te veze (Slika 1), (McAuley \& Blissmer, 2000).

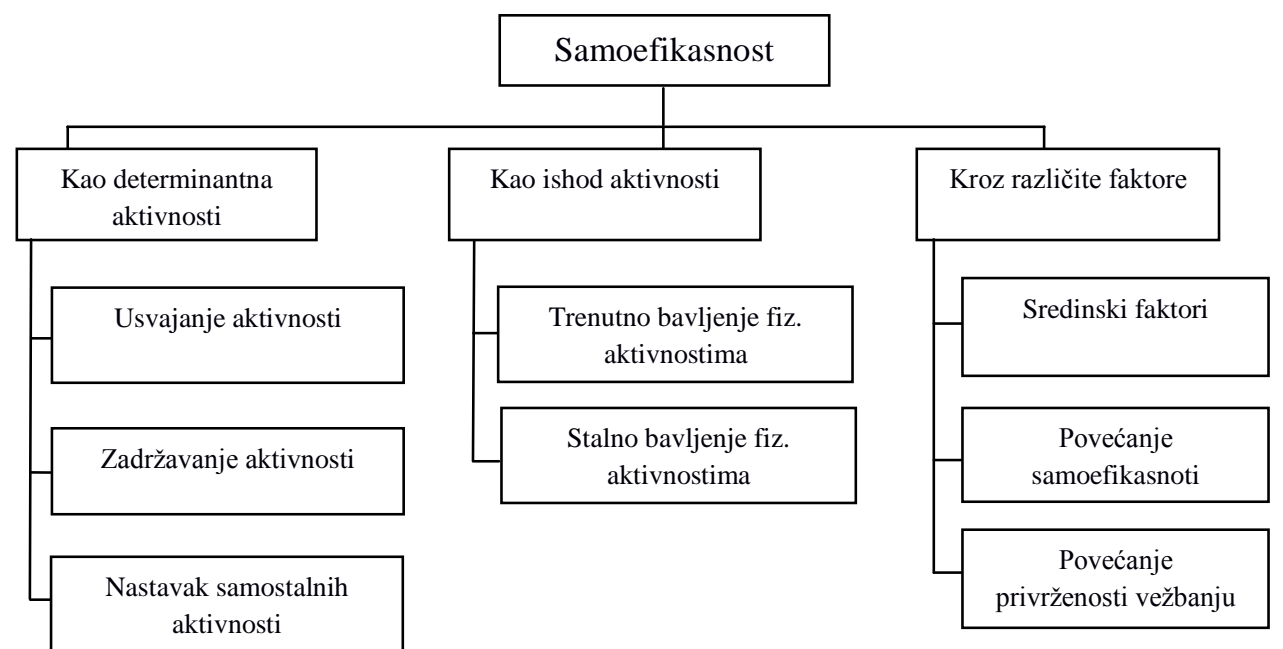

Slika 1 - Shematski prikaz veze između fizičke aktivnosti i samoefikasnosti (McAuley \& Blissmer, 2000: 87)

Samoefikasnost se pokazala kao prediktor početka bavljenja fizičkim aktivnostima i kao značajna determinanta održavanja učešća u fizičkim aktivnostima tokom godina (McAuley \& Blissmer, 2000). Može se zaključiti da samoefikasnost utiče na interesovanja odraslih za fizičke aktivnosti trojako, i to: na samo učešće u ovim aktivnostima; na ishod interesovanja za fizičke aktivnosti i kroz različite faktore koji indirektno takođe utiču na interesovanja kod odrasllih za fizičke aktivnosti (Slika 1). Samoefikasnost kao determinanta fizičkih aktivnosti utiče na samo usvajanje određene aktivnosti, zatim na njeno zadržavanje i kontinuirano bavljenje određenom aktinosti i, na kraju, na nastanak individualnog interesovanja odnosno nastavak samostalnog učešća u fizičkim aktivnostima. Dalje, samoefikasnost utiče na ishode fizičkih aktivnosti $i$ to se prikazuje kroz trenutna $i$ 
kontinuirana interesovanja za fizičke aktivnosti odraslih. Na kraju, recipročnu vezu interesovanja za fizičke aktivnosti i učešća odraslih u njima i samoefikasnosti predstavljaju faktori sredine, povećanje samoefikasnosti, kao i povećanje privrženosti interesovanjima za fizičke aktivnosti odraslih.

$\mathrm{Na}$ osnovu ovog prikaza, možemo zaključiti da je osećanje samoefikasnosti značajan prediktor u interesovanjima za fizičke aktivnosti. Da bi se ova interesovanja razvila i kasnije zadržala, neophodno je da osoba veruje u sebe i da svoje aktivnosti vidi kao uspešne.

\section{ZAKLJUČAK}

U ovom teorijskom istraživanju, na osnovu izučavane literature, analizirani su samorazvoj i samoefikasnost u kontekstu interesovanja odraslih za fizičke aktivnosti. Iako su predmet brojnih nauka i naučnih disciplina, ne postoji još uvek jednoznačna definicija interesovanja, njihovih karakteristika i vrsta. Interesovanja se menjaju sa uzrastom i promenom životne situacije a postaju stabilna u odraslom dobu.

Iako istraživanja ukazuju da je svetska populacija fizički neaktivna više nego ikada pre, te da broj bolesti i posledica sedentarnog načina života rastu (WHO, 2002), i dalje je nedovoljan broj istraživanja koja bi procenila šta je to što određuje da li će odrasli biti fizički aktivni ili ne.

Dosadašnja istraživanja pokazala su da se - kao najdominantnije karakteristike svih interesovanja - izdvajaju: biološka dispozicija, socijalni činioci, ostvaren uspeh $\mathrm{u}$ određenoj aktivnosti, inteligencija individue (Savićević, 1992), ali i samorazvoj i samoefikasnot, čije smo teorijske osnove analizirali $\mathrm{u}$ ovom radu $\mathrm{u}$ kontekstu interesovanja odraslih za fizičke aktivnosti. 
Zaključak je da je samorazvoj praktično dinamički proces traganja za sobom, odnosno nastajanje onog što osoba jeste. Samorazvoj u kontekstu interesovanja za fizičke aktivnosti odraslih analiziran je ovde iz tri ugla: kretanja ka autonomnosti; razvojnih zadataka i self koncepta. Sva tri koncepta su neophodna kako bi osoba razvila stabilno individualno interesovanje za fizičke aktivnosti u odraslom dobu.

S obzirom da su istraživanja pokazala da na većinu aktivnosti i izbora u ljudskom životu u značajnoj meri utiče samoefikasnost (Bong \& Skaalvik, 2003) i da je percipirana samoefikasnost jedan od ključnih pokretača i razlog zadržavanja u fizičkim aktivnostima (Dzewaltowski, Noble, \& Shaw, 1990; Feltz \& Riessinger, 1990; McAuley, 1992, 1993; Shaw, Dzewaltowski, \& McElroy, 1992), logično je bilo da je uključimo u ovo teorijsko istraživanje. Sumiranjem rezultata analize dostupne literature, može se reći da samoefikasnost utiče na ovu vrstu interesovanja kao determinanta same aktivnosti - kroz usvajanje aktivnosti, njeno zadržavanje i nastavak samostalnog bavljenja određenom aktivnošću; kao ishod aktivnosti - kroz trenutno i kontinuirano bavljenje fizičkim aktivnostima i kroz različite faktore - sredinski faktori, povećanjem samoefikasnosti i privrženošću vežbanjem (McAuley \& Blissmer, 2000).

Iz svega navedenog može se uočiti da samorazvoj i percipirani osećaj samoefikasnosti potencijalno predstavljaju značajne prediktore interesovanja odraslih za fizičke aktivnosti. Kako je teorijsko utemeljenje bitna pretpostavka za svako empirijsko istraživanje, trebalo bi da naredna istraživanja budu usmerena na proveru u kojoj meri i u kojim vrstama fizičkih aktivnosti samorazvoj i samoefikasnost utiču na interesovanja za fizičke aktivnosti odraslih. Time bi se mogao steći uvid u kojoj meri postoji 
recipročna veza između samoefikasnosti i samorazvoja i učešća odraslih u fizičkim aktivnostima. Ovo je posebno značajno zbog uticaja koji fizička aktivnost ima na biopsihosocijalne karakteristike pojedinca. U tom smislu, važna i potencijalna istraživačka tema bila bi uticaj samoefikasnosti i samorazvoja na interesovanja odraslih za fizičke aktivnosti.

\title{
A THEORETICAL BASIS OF SELF-DEVELOPMENT AND SELF-EFFICACY OF ADULTS IN THE CONTEXT OF THEIR INTERESTS FOR PHYSICAL ACTIVITIES
}

\begin{abstract}
Interests represent a relatively permanent orientation of an individual's activity toward a particular object. Although the interests are significant in all ages, they represent personality dispositions in adulthood. Besides its definition, the complexity of the phenomenon of the interest indicates the existence of a large number of its characteristics. From the theoretical point of view, the paper analyzes self-efficacy and self-development as characteristics of the interest of adults in physical activities, which have proven to be significant factors in empirical research. The self-development has been observed from three sides: the movement towards autonomy, or self-initiative of the individual; development tasks, and self-concept of the individual. There has been analyzed the self-efficacy as well, which determines our behavior and activities in a particular interest. There has been given an overview of the perceived self-efficacy and participation of adults in physical activities. Summarizing the results concluded that the next research should be directed to check in which types of physical activity self-development and self-efficacy affect the interests of physical activity of adults.
\end{abstract}

KEY WORDS: interests, self-development, self-efficacy, adults, physical activity. 


\section{REFERENCE}

Bandura, A. (1977). Self - efficacy; Toward a unifying theory of behavioral change. Psychologycal Review, 84, 191-215.

Bandura, A. (1997). Self-Efficacy: The Exercise of Control, New York: Freeman.

Bandura, A., Caprara, G. V., Barbaranelli, C., Gerbino, M., \& Pastorelli C. (2003). Role of affective self-regulatory efficacy on diverse spheres of psychosocial functioning. Child Development, 74, 769-782.

Bong M., \& Skaalvik E. M. (2003). Academic Self-Concept and SelfEfficacy: How Different Are They Really? Educational Psychology Review, 15(1), 1-40.

Brandtstadter, J. (1998). Action perspectives on human development. In W. Damon (Series Ed.) \& R. M. Lerner (Vol. Ed.), Handbook of child psychology: Vol. 1. Theoretical models of human development (5th ed., pp. 807-863). New York, NY: Wiley.

Dzewaltowski, D. A., Noble, J. M., \& Shaw, J. M. (1990). Physical activity participation: Social cognitive theory versus the theories of reasoned action and planned behavior. Journal of sport and Exercise Psychology, 12(4), 388-405.

Epstein, S. (1973). The self-concept revisited or a theory of a theory. American Psychologist, 28, 405-416.

Feltz, D. L., \& Riessinger, C. A. (1990). Effects of in vivo emotive imagery and performance feedback on self-efficacy and muscular endurance. Journal of Sport and Exercise Psychology, 12, 132-143. 
Gist, M. E., \& Mitchell, T. R. (1992). Self-efficacy: A theoretical analysis of its determinants and malleability. Academy of Management Review, 17 (2), 183-211.

Hofer, M. (2010). Adolescent 'Development of Individual Interst: A Product of Muzltiple Goal Regulation? Educational Psychologist, 45(3), 149166.

Maddux, J. E. (2002). Self-efficacy: The power of believing you can. In C.R. Snyder \& S.J. Lopez (Eds.), Handbook of positive psychology (pp. 277-287). New York: Oxford University Press.

Maddux, J. E., \& Gosselin, J. T. (2003). Self-efficacy. In: Leary MR, Tangney JP, editors. Handbook of Self and Identity. New York, NY, USA: Guilford Press; pp. 218-237.

McAuley, E. (1992). The role of efficacy cognitions in the prediction of exercise behavior in middle-aged adults. Journal of Behavioral Medicine, 15 (1), 65-88.

McAuley, E. (1993). Self-efficacy and the maintenance of exercise participation in older adults. Journal of Behavioral Medicine, 16, 103113.

McAuley, E., \& Blissmer, B. (2000). Self - Efficacy Determinants and Consequences of Physical Activity. Exercise and Sport Science Reviews, 2 (28) 85-88.

Oljača, M. (1992). Samoobrazovanje $i$ samorazvoj odraslih. Novi Sad: Institut za pedagogiju - Filozofski fakultet.

Oljača, M. (2001). Pedagogija sporta. Beograd: Sportska akademija. Oljača, M. (2005). Self koncept i razvoj. Novi Sad: Filozofski fakultet. Oljača, M. (2013). Andragoška didaktika. Novi Sad: Filozofski fakultet. 
Pantić, D. (1982). Interesovanje. Sociološki leksikon. Beograd: Savremena administracija.

Pedagoški leksikon. (1996). Beograd: ZZUINS.

Redmond, B. F. (2010). Self-Efficacy Theory: Do I think that I can succeed in my work? Work Attitudes and Motivation. The Pennsylvania State University: World Campus. Pristupljeno 28.04.2017. https://cms. psu.edu.

Rogers, C. R. (1961). On Becoming a Person, A Therapist's View of Psychotheraphy. Boston, Massachusetts: Houghtrom Mifflin.

Saks, A. M. (1995). Longitudinal field investigation of the moderating and mediating effects of self-efficacy on the relationship between training and newcomer adjustment. Journal of Applied Psychology, 8 (2), 211225.

Savićević, D. (1992). Priroda i karakteristike interesa u andragogiji. Beograd: ZZUINS - Filozofski fakultet.

Shaw, J. M., Dzewaltowski, D. A., \& McElroy, M. (1992). Self-efficacy and causal attributions as mediators of perceptions of psychological momentum. Journal of Sport and Exercise Psychology, 14 (2), 134147.

Silver, W. S., Mitchell, T. R., \& Gist, M. E. (1995). Responses to successful and unsuccessful performance: The moderating effect of self-efficacy on the relationship between performance and attributions. Organizational Behavior and Human Decision Processes, 62 (3), 286-299.

Strang, R. (1957). The Adolescent Views Himself. New York: McGraw Hill. 
Trost, G., Owen, N., Bauman, E., Sallis, F., \& Brown W. (2002). Correlates of adults' participation in physical activity: review and update. Medicine and Science in Sports and Exercise, 34, 1996-2001.

WHO (World Health Organization). (2002). The World health report 2002 Reducing risks, promoting healthy life. Geneva: World Health Organization. http://www.who.int/whr/2002/en, pristupljeno 26.05.2015. 